\title{
Beyond ruminants: discussing opportunities for alternative pasture uses in New Zealand
}

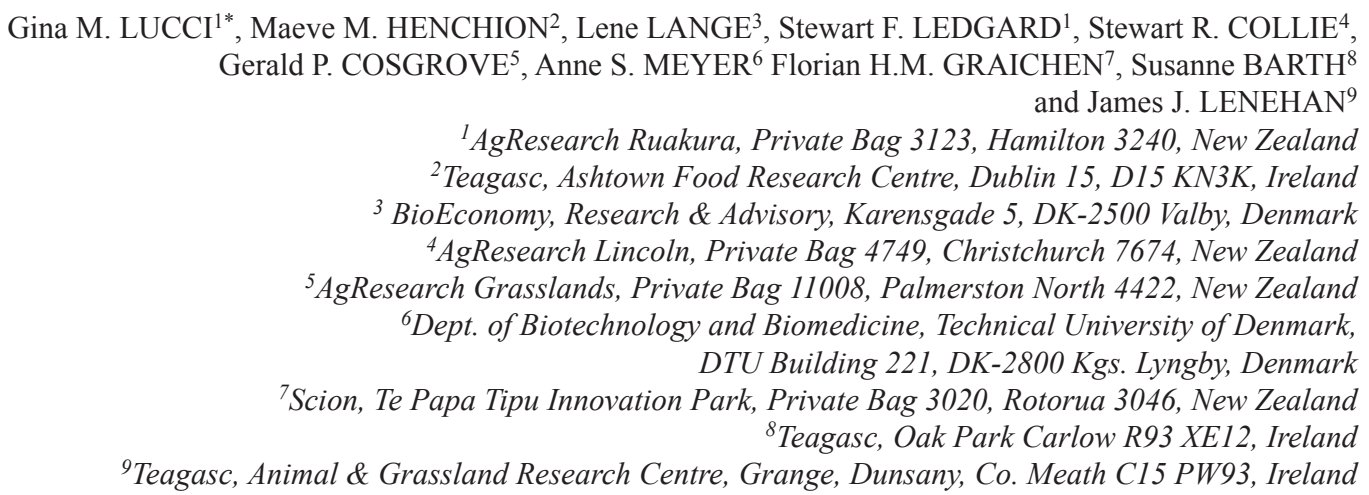
*Corresponding author: Gina.Lucci@agresearch.co.nz

\begin{abstract}
The New Zealand government has set ambitious goals for primary sector growth and of zero net carbon emissions by 2050 . This presents an opportunity and obligation to develop new ideas for grassland production systems to increase export value and generate new job opportunities, while reducing environmental impacts. The aim of this paper is to draw on recent research in Europe to investigate some of the alternative and complementary uses for pasture as a feedstock for a green biorefinery. A biorefinery is a facility, or a series of processes, that convert biomass into a spectrum of value-added products. For example, protein can be extracted mechanically from green biomass once harvested. The residual fibre fraction could be used as a low-nitrogen feed for ruminants to reduce urinary nitrogen, while the liquid protein fraction could be processed to make it suitable for mono-gastric or human consumption. Enzymes can promote protein extraction and controlled conversion of insoluble plant fibres and oligosaccharides to foster gut-health promoting prebiotic food ingredients. Anaerobic digestion of residues can then be used to create energy and soilimproving products. Research and demonstration of these approaches in practice, along with the results of feasibility studies, will be required to see which of these opportunities is a good fit for New Zealand pasture systems.
\end{abstract}

Keywords: Pasture, feed, fibre, anaerobic digestion, protein

\section{Introduction}

In New Zealand, as in many countries, governments have set ambitious goals for the primary sector to grow their bioeconomies. It is expected that this will lead to more efficient use of biological resources, climate change adaptation and mitigation, increased biodiversity, and job creation, especially in rural areas. However, internationally agreed environmental goals for greenhouse gas emissions (e.g. Paris Agreement) and water quality standards (e.g. New Zealand National Policy Statement for Freshwater, and EU Water Framework Directive) will likely limit the growth of some pasture-based industries. Moreover, environmental concerns coupled with changing consumer preferences could lead to a reduction in livestock numbers, or removal of livestock altogether from some areas. Rather than a cause for concern, this presents an opportunity to consider the possibilities for new, value-added products, value chains and industries based on pasture.

The Royal Society Te Apārangi Catalyst Fund facilitates new small and medium pre-research strategic partnerships. Support from this fund was used to establish a consortium of Danish, Irish and New Zealand scientists to develop ideas regarding the alternative uses for pasture that have potential application in New Zealand. The aim of this paper is to briefly discuss the learnings from new research and pilot projects underway in Europe. Some of the possible alternatives have been considered previously (e.g. Sinclair \& McManus 2009) but were shown at that time to be economically unviable. However, we believe they should be re-examined due to recent advances in bio-polymer, bio-fuel and enzymatic technology. In addition, societal pressures are now very different, more complex and could change further (e.g. the Climate Change Response [Zero-Carbon] Amendment Bill). These drivers make alternative pasture uses more attractive and viable, and have stimulated considerable new research on these new opportunities in Europe. 
In this period of changing social, economic and climatic pressures, we need to generate new ideas and approaches for pasture production systems that increase export value, generate new job opportunities and reduce environmental impacts.

\section{Pasture as a bio-resource}

Pasture is a rich, readily available source of plant material with interesting, and so far underexploited, value-addition potential. In this paper pasture is defined as a "plant community dominated by grasses, herbaceous legumes and other herbaceous species" (Thomas 1980). From a ruminant nutrition perspective, pasture composition is usually described in terms of structural (fibre) and non-structural (soluble sugars and starch) carbohydrates (10-30\%), protein (11-28\%; with $1-8 \%$ of this being non-protein forms of nitrogen), lipids and waxes (3-5\%), lignin (3-4\%), organic acids $(2-3 \%)$ and ash (largely minerals; $8-12 \%)$. These constituents can be used for multiple purposes such as food, feed, fuel, and fibre. Biorefining presents a process through which these multiple product options can be developed.

Silage, rather than fresh pasture, may also be used in a biorefinery. Silage allows for a continuous supply and consistent quality of feedstock, compared with the seasonal variation in pasture production volume and composition. However, the fermentation process may change the composition of some of the major constituents in silage (e.g. protein, fibre and carbohydrate). Soluble sugars are converted to lactic acid during the ensiling process or lost in respiration before the conversion process is curtailed by low $\mathrm{pH}$. In addition, significant loss of protein occurs via proteolytic and microbial degradation (McDonald \& Whittenbury 1973). These losses of specific constituents during the ensiling process and storage may offset some of the advantages associated with using silage instead of fresh herbage as a feedstock. However, this conversion might be useful in some circumstances as a first step for bioplastics production and would then be considered a part of the biorefinery system.

\section{Biorefinery concept}

A biorefinery (Figure 1) is a facility, or a series of processes, that converts biomass into a spectrum of value-added products ranging from food and feed additives, to fine chemicals and chemical "building block" compounds, to fuel and (bio)energy. The key idea is efficient resource utilisation, meaning production without waste or side streams. Analogously, a 'green biorefinery' is a facility that can process green biomass (e.g. pasture) into a range of products (McEniry \& O'Kiely 2014). Classically, the first step

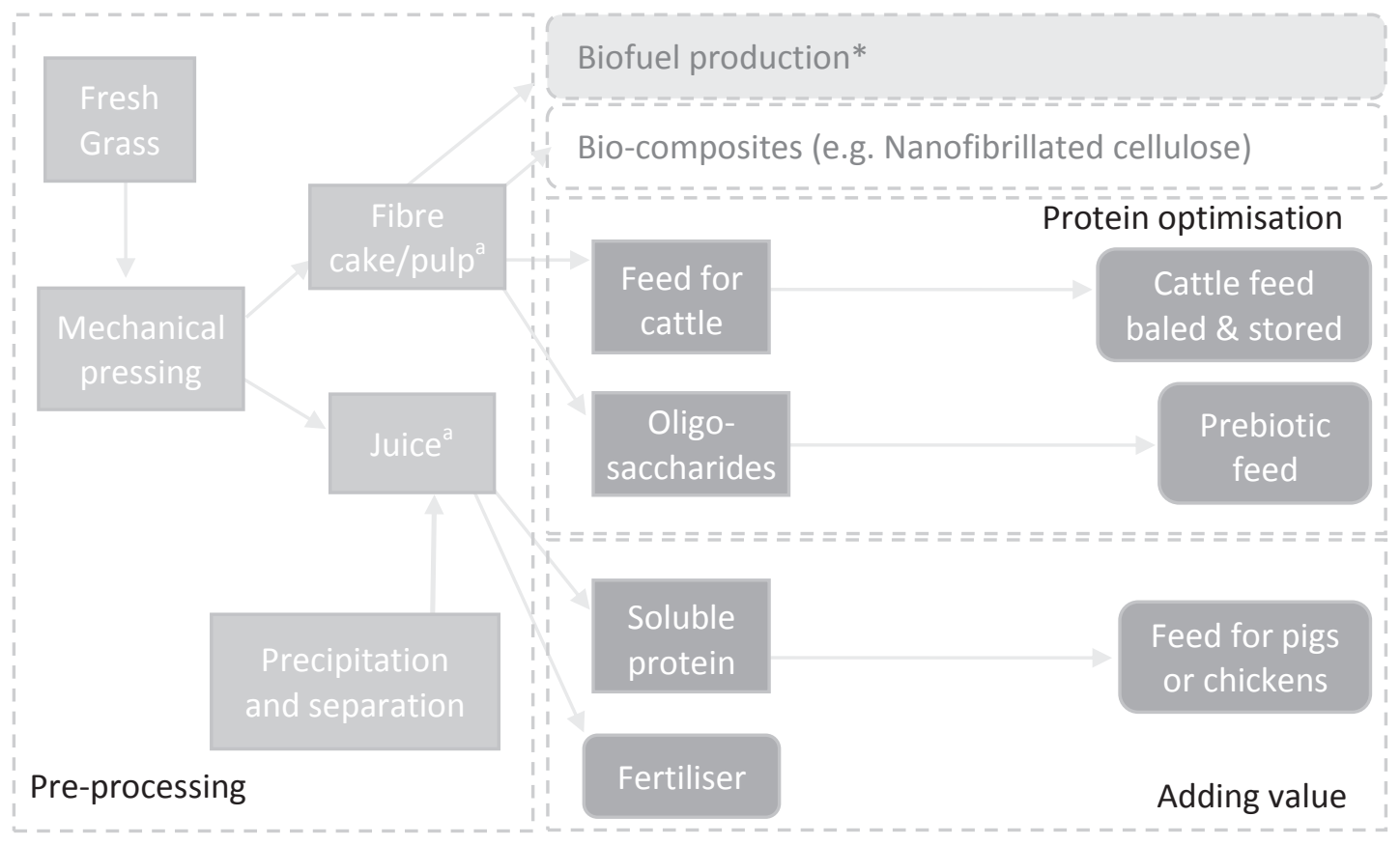

\section{Multi-product Biorefinery}

Figure 1 A generic overview of potential processes and products from a green biorefinery. Adapted from Biorefinery Glas (J.

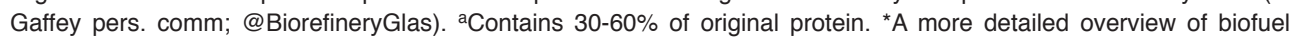
production is provided in Figure 2. 
of a green biorefinery is the mechanical separation of the fibre from the juice, usually via screw pressing in the pre-processing stage (Figure 1). Many valuable components like protein and lactic acid are in the press juice. From there, further fractionation can occur via mechanical (e.g. centrifugation), chemical (e.g. acid precipitation), thermal, or enzymatic means to extract and refine individual components.

In Denmark, perennial pasture used for resource extraction and bioenergy production is seen as an alternative to annual cereal cropping to reduce nutrient losses to waterways (Odgaard et al. 2019). Another example is the "GRASSA!" biorefinery project in the Netherlands (www.grassa.nl) that produces bales of fibre cake for cattle feed; a protein concentrate for chicken feed; a soluble dietary fibre supplement; and a fertiliser concentrate, all from pasture. In Ireland, on-farm demonstration of a small-scale mobile grass biorefinery is underway to produce and validate multiple feed, food and fertiliser applications (https://biorefineryglas.eu/). The results from the Netherlands, Denmark (Dotsenko $\&$ Lange 2017) and Ireland suggest that multiple valuechain products from the green biorefinery could be produced from pasture feedstock alone.

\section{Potential uses}

\section{Feed products: Low- $N$ feed}

In New Zealand, fresh pasture typically has a higher protein content than ruminant requirements. The excess protein not retained for growth or production is excreted in urine at localised, high $\mathrm{N}$ concentrations. This $\mathrm{N}$ is highly vulnerable to leaching, leading to pollution of waterways and increased GHG emissions. Reducing $\mathrm{N}$ intake is highly effective in reducing $\mathrm{N}$ output in ruminants (Pacheco et al. 2008). Therefore, the fibre cake, with 40 to $60 \%$ of the protein content of fresh pasture, could be a valuable low protein feed supplement. Preliminary analyses for an average Waikato dairy farm where $25 \%$ of pasture was harvested (instead of grazed in situ), two-thirds of the protein extracted, and the residue returned into the system as a low- $\mathrm{N}$ energy feed (like maize silage), were run through the OVERSEER model (Wheeler et al. 2007). It indicated a reduction in $\mathrm{N}$ leaching of $30 \%$ compared to that where all pasture was grazed directly.

\section{Feed products: Protein-rich and prebiotic animal feed}

Recovery of plant protein is an important part of green biomass biorefining. Recent data on white clover and ryegrass (Dotsenko \& Lange 2017) showed that whilst about $40 \%$ of protein was recovered by slightly alkaline aqueous extraction, the addition of a commercial protease enzyme blend (Savinase 16.0L, Novozymes) close to doubled the protein yield.

Oligosaccharides from pasture press pulp preferentially stimulate the growth of desirable bacteria and suppress the growth of undesirable bacteria and could therefore be used as gut-health promoting feed for non-ruminant animals (Figure 1). In a recent study, one such beneficial type of oligosaccharides; xylooligosaccharides, was enzymatically extracted from heat-pretreated ryegrass and shown to exert putatively prebiotic, gut-beneficial effects in vitro on pig fecal microbiota by suppressing potential pathogen growth (Clostridium perfringens) and stimulating the growth of lactic acid bacteria (Dotsenko et al. 2018). There might be similar options for extracting and/ or selectively modifying other types of potentially beneficial oligosaccharides (e.g. fructans) from grass to generate new, value-added pasture-based biorefinery products.

The increasing restrictions on the use of antimicrobial growth promotors in animal feed, the recognition that grass biomass carbohydrates represent a source of putative prebiotics for animals (and maybe with time even for humans), and improved next-generation sequencing options for gut-microbiome analyses have paved the way for two important steps forward: 1) evidence-based development of gut-health promoting animal feed additives that may replace antimicrobial growth promotors; and 2) new options for providing evidence that a healthier gut microbiome can lead to increased robustness of e.g. piglets. Together, these open opportunities to reduce the need for, and use of, antibiotic treatments in industrial meat production, thereby also reducing the risk for development of antibiotic resistance like methicillin-resistant Staphyloccus aureus (MRSA). We consider that targeted development of prebiotic products from grassland crops holds vast potential for improving animal production, and that such a target provides options for transforming grassland production systems to involve biorefining (Figure 1).

\section{Energy/Biofuel}

Biogas can be produced through anaerobic digestion (AD) of organic wastes, including grass as a high-grade feedstock. Energy crops have not been widely embraced in New Zealand despite systems analysis showing the potential benefits of its integration with dairy and beef enterprises dating back more than 30 years (e.g. Piggot 1983). It has been estimated that $\mathrm{AD}$ of just $10 \%$ of grasslands in Ireland could fuel $55 \%$ of their private car fleet (Smyth et al. 2009). A newly constructed anaerobic digestion facility in Ireland combines cattle slurry and silage (Figure 2) to create biogas with the digestate returned to land as fertiliser. Biogas can be upgraded to biomethane (through partitioning of $\mathrm{CO}_{2}$ ) and used as a replacement for natural gas and can thus be used for transport and thermal energy demands, not just electricity generation. The extraction of proteins from 


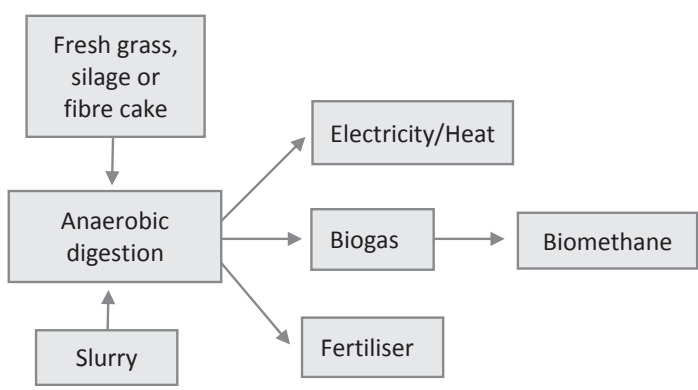

Figure 2 Overview of energy production from pasture, or from pasture-based biorefinery products, via anaerobic digestion. Combining energy production with higher value animal feed additives (Figure 1) can create additional value.

grass carried out prior to the AD process should not compromise the production of biogas, and in fact should improve the performance of the digestion process as high nitrogen levels in the feedstock can have a negative impact on the growth of bacteria which produce the biogas. Moreover, the commercial viability of biogas production is strengthened by generating additional value from production of animal feed additives. The digestate produced as a by-product of the AD process can be used as a replacement for chemical fertiliser and could be used as a tool to reduce GHG emissions from agriculture. For example, Boscaro et al. (2018) estimated AD facilities using pasture feedstock would save $181-233 \mathrm{~kg} \mathrm{CO}_{2} \mathrm{eq} / \mathrm{t}$ DM compared with fossil fuels.

\section{Bioplastics and Bio-composite Materials}

Polyhydroxyalkanoates (PHAs) are versatile bioplastics with a range of potential forms and applications, which can be produced from a wide variety of bioresource streams (Rodriguez-Perez et al. 2018). They have been produced in the laboratory from pasture-based feedstocks that underwent simple preliminary processing steps, before fermentation, using bacteria which deposit PHAs within their cells under appropriate conditions. Perennial ryegrass was used as a feedstock for PHA production by Pseudomonas spp., after having been subjected to preparatory treatment with sodium hydroxide or hot water (Davis et al. 2013). After delignification, the treated grass was enzymatically hydrolysed into simple sugars that were then able to be fermented to produce PHA. In a similar study, surfactant treatment in a hydrothermal reactor was used as the first step before enzymatic treatment and subsequent PHA production (Kataria et al. 2018). Ensiled grass press juice, rich in mannitol, was used a feedstock in one study (Cerrone et al. 2015), while volatile fatty acids from anaerobicallydigested grass have also been used to make medium chain length PHA (Cerrone et al. 2014).

Cellulose fibres are known for their applicability in eco-friendly composite materials, although unlocking their full potential remains a challenge for load-bearing engineering applications. Growing environmental awareness and increasing interest in sustainable materials have led to the development of bio- and green composites for structural composite applications (Huber et al. 2012). Following the biorefinery concept (Figure 1), the residual pressed fibre cake from fresh and ensiled ryegrass was used to make nanofibrillated cellulose (NFC) under a range of conditions (Sharma et al. 2012). Composite materials made using the NFCs showed commercially useful mechanical and thermal attributes. Furthermore, at least one commercial product exists that uses cellulose fibres extracted from meadow grass, combined with a thermoplastic matrix polymer (https://biowert.com/products/agriplast). This is prepared in pelletised form and can be injectionmoulded or extruded into a range of product formats.

\section{Discussion}

\section{Challenge: Demonstration and value proposition}

Most of the technologies mentioned above have shown enough promise to proceed to demonstration or pilotscale projects in Europe. Research and demonstration of these approaches in practice, along with the results of feasibility studies, will be required to see which of these opportunities is a good fit for New Zealand pasture systems. As highlighted in Figure 1, there are many potential end-products from a green biorefinery. Biorefining and anaerobic digestion provide two routes to develop new products from pasture. There is merit in considering their use in sequence rather than in parallel. Indeed, the development of multiple coproducts may be required in order to be economically viable. Such thinking, which reflects the cascading principle, requires new value chains not to be evaluated in isolation but to be evaluated in a more integrated manner than has previously been attempted.

\section{Challenge: Evaluation}

Models need to be developed to evaluate trade-offs that may arise as a consequence of using pasture for alternative purposes to ensure a net benefit is realised. For example, producing more pasture from the same land base may require more fertiliser and greater energy inputs from harvesting grass mechanically, compared with grazing. Such systems may not reduce overall emissions. Furthermore, trade-offs between economic, social and environmental objectives need to be considered from a policy perspective when determining the optimal scale of such opportunities.

\section{Challenge: Scale}

Scale may be a problem for harvesting and transport of pasture in some areas and landscapes, but technologies 
are rapidly evolving that would make smaller, mobile bio-refineries a viable alternative in the future. Green biorefineries in demonstration scale have been established in The Netherlands, Denmark and Ireland, and commercial scale plants are under construction. Spatial analysis is also required to identify optimal distances to transport harvested pasture, keeping in mind that supply distance and logistics is a key determinant of environmental impact of the supply chain (Boscaro et al. 2018). Investment in infrastructure development will also be needed (e.g. GRAZE https:// bioenergyinternational.com/biogas/graze-gas-a-majorstep-for-gas-networks-ireland).

\section{Challenge: Land use}

Changes in land use could be a driver towards utilisation of land for uses other than feed and commodity production. Land at high risk of nutrient loss to waterways under grazing, could lend itself towards biorefinery applications. Steps to facilitate changes in land use towards biorefinery exploitation would be to identify and breed the most suitable, productive plant species, and then adapt or optimise agricultural production practices. Marginal lands could also be considered for optimising pasture biomass production for biorefinery use (Jones et al. 2015).

\section{Conclusions}

Harvesting pasture and using it as a feedstock for a green biorefinery presents a new opportunity to invigorate pasture farming by generating additional income from local production of new feed, food, fibre and energy products, and substitution of imported protein sources. Furthermore, the use of biorefining and anaerobic digestion can be considered as complementary to, rather than in competition with, traditional pasturebased value chains, particularly if farmers produce more grass more efficiently. Considerable research effort on these options is going on in Europe and there is a need to examine their potential for New Zealand to increase rural diversity and meet social, environmental and economic goals. In the longer term, through these new industries, we may be able to displace other high GHG-emission products and energy sources and move towards carbon neutral pasture-based farming systems.

\section{ACKNOWLEDGEMENTS}

The authors would like to thank the Royal Society Te Apārangi for the Catalyst: Seeding funding that supported the travel, site visits and workshops that made this consortium possible.

\section{REFERENCES}

Boscaro D, Pezzuolo A, Sartori L, Marinello F, Mattioli A, Bolzonella D, Grigolato S. 2018. Evaluation of the energy and greenhouse gases impacts of grass harvested on riverbanks for feeding anaerobic digestion plants. Journal of Cleaner Production 172: 4099-4109.

Cerrone F, Davis R, Kenny ST, Woods T, O’Donovan A, Gupta VK, Tuohy M, Babu RP, O'Kiely P, O'Connor K. 2015. Use of a mannitol rich ensiled grass press juice (EGPJ) as a sole carbon source for polyhydroxyalkanoates (PHAs) production through high cell density cultivation. Bioresource Technology 191: 45-52.

Cerrone F, Choudhari SK, Davis R, Cysneiros D, O'Flaherty V, Duane G, Casey E, Guzik MW, Kenny ST, Babu RP, O'Connor K. 2014. Medium chain length polyhydroxyalkanoate (mcl-PHA) production from volatile fatty acids derived from the anaerobic digestion of grass. Applied Microbiology and Biotechnology 98(2): 611-620.

Davis R, Kataria R, Cerrone F, Woods T, Kenny S, O'Donovan S, Guzik M, Shaikh H, Duane G, Gupta VK, Tuohy MG,. Padamatti RB, Casey E, O'Connor $\mathrm{KE}$ 2013. Conversion of grass biomass into fermentable sugars and its utilization for medium chain length polyhydroxyalkanoate (mcl-PHA) production by Pseudomonas strains. Bioresource Technology 150: 202-209.

Dotsenko G, and Lange L. 2017. Enzyme enhanced protein recovery from green biomass pulp. Waste Biomass Valor 8:1257-1264

Dotsenko G, Meyer AS, Canibe N, Thygesen A, Nielsen MK, Lange L. 2018. Enzymatic production of wheat and ryegrass derived xylooligosaccharides and evaluation of their in vitro effect on pig gut microbiota. Biomass Conversion and Biorefinery 8:497-507

Huber T, Müssig J, Curnow O, Pang S, Bickerton S, Staiger MP. 2012. A critical review of all-cellulose composites. Journal of Materials Science 47(3): 1171-1186.

Jones MB, Finnan J, Hodkinson TR. 2015. Morphological and physiological traits for higher biomass production in perennial rhizomatous grasses grown on marginal land. GCB Bioenergy 7: 375-385

Kataria R, Woods T, Casey W, Cerrone F, Davis R, O'Connor K, Ruhal R, Babu R. 2018. Surfactantmediated hydrothermal pretreatment of ryegrass followed by enzymatic saccharification for polyhydroxyalkanoate production. Industrial Crops and Products 111: 625-632.

McDonald P. and Whittenbury R. 1973. The ensiling process. In: Butler GW, Bailey RW Eds. The Chemistry and Biochemistry of Herbage. Volume 3. Academic Press, London and New York. Pp. 33-60.

McEniry J, O'Kiely P. 2014. Developments in grass-/ forage-based biorefineries. In Waldron $\mathrm{K}$ Ed. 
Advances in Biorefineries. Woodhead Publishing, UK. Pp. 335-363.

Odgaard MV, Knudsen MT, Hermansen JE, Dalgaard T. 2019. Targeted grassland production - A Danish case study on multiple benefits from converting cereal to grasslands for green biorefinery. Journal of Cleaner Production 223: 917-927.

Pacheco D, Waghorn GC. 2008. Dietary nitrogen definitions, digestion, excretion and consequences of excess for grazing ruminants. Proceedings of the New Zealand Grassland Association 70: 107-116.

Piggot GJ. 1983. Integrating livestock and sugar-ethanol production and the dairy industry in Northland concept. Proceedings of the New Zealand Society of Animal Production 43:107-109.

Rodriguez-Perez S, Serrano A, Pantión AA, AlonsoFariñas B. 2018. Challenges of scaling-up PHA production from waste streams. A review. Journal of Environmental Management 205: 215-230.

Sinclair, S, McManus, R. 2009. Protein extraction from pasture cost-benefit analysis: A feasibility study evaluation of both investment and economic implications. A report prepared for the Sustainable Farming Fund, Ministry of Agriculture and Forestry, and the Pastoral Greenhouse Gas Consortium. SFF
Grant Number C08/001. 73 p. https://dokumen. tips/download/link/protein-extraction-from-pastureministry-for-primary-maxamafgovtnzsffaboutprojectssearchc08-001 co2017-01-16protein.html

Sharma HSS, Carmichael E, Muhamad M, McCall D, Andrews F, Lyons G, McRoberts WC, Hornsby PR. 2012. Biorefining of perennial ryegrass for the production of nanofibrillated cellulose. RSC Advances 2(16): 6424-6437.

Smyth BM, Murphy JD, O'Brien CM. 2009. What is the energy balance of grass biomethane in Ireland and other temperate northern European climates? Renewable and Sustainable Energy Reviews 13: 2349-2360.

Thomas H. 1980. Terminology and definitions in studies of grassland plants. Grass and Forage Science 35(1): 13-23.

Wheeler DM, Ledgard SF, Monaghan RM. 2007. Role of the OVERSEER ${ }^{\circledR}$ nutrient budget model in nutrient management plans. In: Designing sustainable farms: Critical aspects of soil and water management. Currie LD \& Yates LJ. Eds. Occasional Report No. 20. Fertilizer and Lime Research Centre, Massey University, Palmerston North, New Zealand, pp. 53-58. 